\title{
Wehrlites from continental mantle monitor the passage and degassing of carbonated melts
}

\author{
S. Aulbach ${ }^{1 *}$, A.-B. Lin ${ }^{2,3}$, Y. Weiss ${ }^{4}$, G.M. Yaxley ${ }^{5}$
}

Abstract

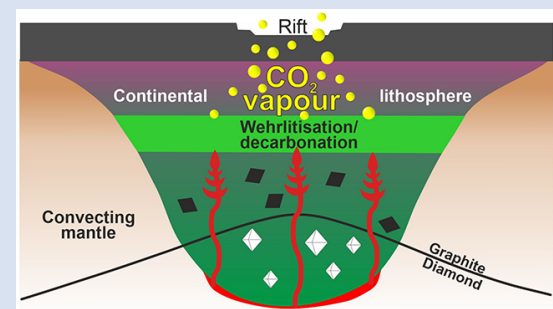

$\mathrm{SiO}_{2}$-undersaturated melts $+\mathrm{CO}_{2} \pm \mathrm{H}_{2} \mathrm{O}$
Continental rifting has been linked to the thinning and destruction of cratonic lithosphere and to the release of enough $\mathrm{CO}_{2}$ to impact the global climate. This fundamental plate tectonic process facilitates the infiltration and mobilisation of smallvolume carbonated melts, which may interact with mantle peridotite to form wehrlite through the reaction: enstatite + dolomite $($ melt $)=$ forsterite + diopside $+\mathrm{CO}_{2}$ (vapour). Application to mantle xenolith suites from various rifts and basins shows that 2.9 to $10.2 \mathrm{~kg} \mathrm{CO}_{2}$ are released per $100 \mathrm{~kg}$ of wehrlite formed. For the Eastern Rift (Africa), this results in estimated $\mathrm{CO}_{2}$ fluxes of $6.5 \pm 4.1 \mathrm{Mt} \mathrm{yr}^{-1}$, similar to estimates of mantle contributions based on surficial $\mathrm{CO}_{2}$ surveys. Thus, wehrlite-bearing xenolith suites can be used to monitor present and past $\mathrm{CO}_{2}$ mobility through the continental lithosphere, ultimately with diffuse degassing to the atmosphere. They may also reveal the $\mathrm{CO}_{2}$ flux in lithospheric provinces where carbonated melts or continent-scale rifts are not observed at the surface.

Received 2 May 2020 | Accepted 17 August 2020 | Published 25 September 2020

\section{Introduction}

The conversion of lherzolite and harzburgite to an orthopyroxenepoor or -free, clinopyroxene-rich rock classified as wehrlite - a process hereafter referred to as wehrlitisation - requires interaction with silica-undersaturated (ultra)basic melts (e.g., Wallace and Green, 1988; Yaxley et al., 1998). Such melts encompass carbonatites, carbonated silicate melts (e.g., kimberlite) or $\mathrm{CO}_{2}$ bearing silicate melts (e.g., melilitites and nephelinites), which can form by near-solidus melting of peridotite (e.g., Gudfinnsson and Presnall, 2005). Given the strong incompatibility of $\mathrm{CO}_{2}$ in peridotite, low-volume melts are typically carbonated even if the source is not specifically C-rich, as long as the mantle source lies above the depth of redox melting (Hirschmann, 2010). In extensional continental settings, small-volume melts generated in the deep lithospheric or convecting mantle traverse 100 to $250 \mathrm{~km}$ of subcontinental lithospheric mantle (SCLM) and crust, with which they are initially out of chemical equilibrium, causing extensive reactions to occur (e.g., McKenzie, 1989). Wehrlitisation can result from such reactions and involves the liberation of $\mathrm{CO}_{2}$ vapour (e.g., Wallace and Green, 1988; Yaxley et al., 1998). This, in turn, contributes to diffuse continental degassing, especially in rift settings where lithosphere thinning has occurred (Brune et al., 2017; Foley and Fischer, 2017). It is noticeable that wehrlites are frequently reported in the literature for basalt-borne xenolith suites associated with rifts, faults and basins. These structures are pathways for $\mathrm{CO}_{2}$-rich fluids (Tamburello et al., 2018). However, a link between the release of $\mathrm{CO}_{2}$ to the exosphere during diffuse, non-volcanic degassing and a specific petrological mechanism remains unexplored, and the passage of carbon through the lithosphere is itself poorly documented. Wehrlite-bearing xenolith suites have been entrained in magmas of various ages. Using literature data, we show that wehrlites, as both products and monitors of the passage of $\mathrm{CO}_{2}$-bearing melts, can reveal the otherwise hidden $\mathrm{CO}_{2}$ flux through the shallow SCLM, and its eventual tectonic degassing both in currently and formerly active rifts.

\section{Depths, Hallmarks and Agents of Wehrlitisation}

Published data show that basalt-borne xenolith suites from the spinel facies SCLM ( 40-100 km), mostly associated with offcratonic lithosphere or cratonic lithosphere in various states of disruption and decratonisation, contain significant proportions of wehrlite (Table S-1). The data compilation encompasses garnet-free xenoliths from various on- and off-cratonic rift systems and basins (Supplementary Information). Indeed, the decarbonation reaction, which causes wehrlitisation, has been experimentally demonstrated to occur at relatively shallow depths corresponding to 1.5 to $2.0 \mathrm{GPa}$ (Wallace and Green, 1988, and references therein). This is because the carbonated peridotite solidus features a "ledge" in pressure-temperature space so that on upward movement of carbonatite melts, they must freeze and react to form wehrlites (Wallace and Green

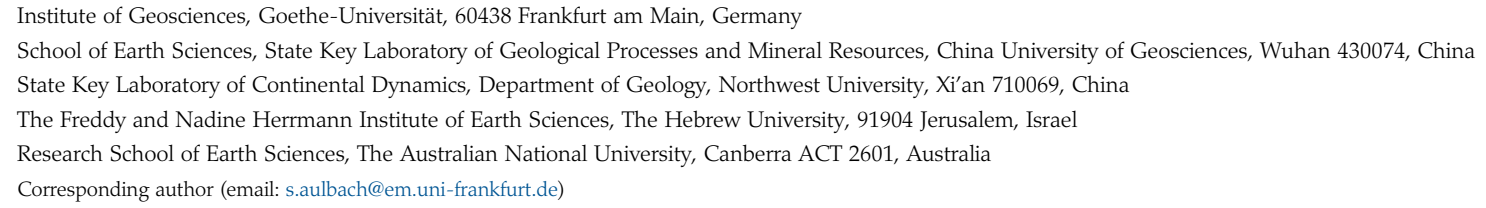


1988). There is pervasive evidence for the interaction of $\mathrm{SiO}_{2}$ undersaturated, $\mathrm{CO}_{2}$-bearing melts also with the deep lithosphere, and carbonatitic high-density fluids are observed in diamonds (Fig. 1, Table S-2). Nevertheless, the proportion of wehrlitic garnet both in xenoliths and as inclusions in diamond is minute $(\sim 1 \%)$ compared to the lherzolite or harzburgite paragenesis (Fig. S-1). Thus, wehrlitisation is not an important process in the garnet- and diamond-stable part of the SCLM (> 60 and $\sim 120 \mathrm{~km}$, respectively, depending on geotherm), which typically records lower oxygen fugacities than the shallow SCLM (Supplementary Information). Interaction of carbonated melts with the deep lithosphere leads to graphite/diamond precipitation instead, through a process called redox freezing (Rohrbach and Schmidt, 2011).

Wehrlitisation leads to high clinopyroxene modes at the expense of orthopyroxene relative to other peridotites in the same xenolith suite. Transitional rock types affected by the same process, but at lower melt-rock ratios, also occur, resulting in
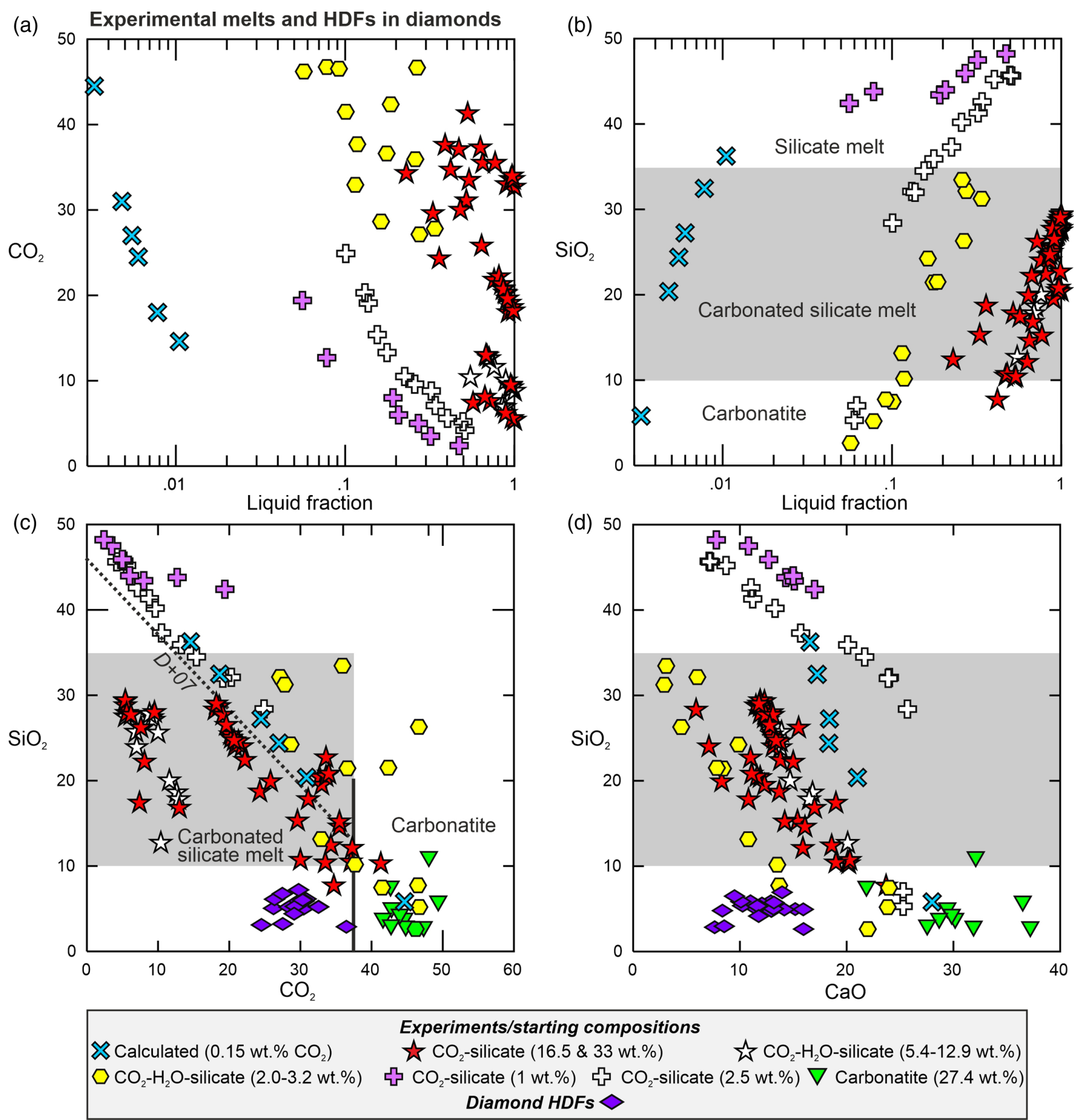

Figure 1 (a-d) Major element (wt. \%) relationships and fractions of liquids ranging from carbonatite to carbonated silicate melt and silicaundersaturated, $\mathrm{CO}_{2}-\left( \pm \mathrm{H}_{2} \mathrm{O}\right)$ bearing silicate melt produced in experiments; high-density fluids (HDFs) in diamonds (Table S-2) shown for comparison. Concentrations of $\mathrm{CO}_{2}$ in the starting mixture are given in parentheses. Differences in liquid composition relate to different starting mixtures, but similarly sloping trends are obtained for the various studies. Trend and separation of carbonatite from carbonated silicate melt in (c) are from Dasgupta et al. (2007). Melt fractions are not reported in all experiments. 
clinopyroxene-rich lherzolites and orthopyroxene-poor harzburgites with clinopyroxene/orthopyroxene ratios $>1$ (e.g., Yaxley and Green, 1996; Lin et al., 2020). Depending on the style of melt interaction (porous flow $v$ s. fractures), olivine-rich, pyroxene-poor to -free dunites may ultimately form (e.g., Shaw et al., 2018). The metasomatic agents inferred for the various wehrlite-bearing xenolith suites range from carbonatite to carbonated silicate melts to $\mathrm{CO}_{2}$-bearing silicate melts (Supplementary Information), which reflect increasing melt volumes and dilution with silicate components (e.g., Gudfinnsson and Presnall, 2005). Based on experimentally produced melts, there is a relationship between melt fraction and $\mathrm{CO}_{2}$ (Fig. 1a) and $\mathrm{SiO}_{2}$ content (Fig. 1b), producing an inverse correlation between $\mathrm{CO}_{2}$ and $\mathrm{SiO}_{2}$ (Fig. 1c) and between $\mathrm{SiO}_{2}$ and $\mathrm{CaO}$ (Fig. 1d). The higher melt volumes involved in the generation of $\mathrm{SiO}_{2}$-rich melts may therefore compensate for their lower $\mathrm{CO}_{2}$ contents in terms of their ability to convert a given amount of orthopyroxene to clinopyroxene. The link between silica-undersaturated carbonated melts, wehrlites and decarbonation at low pressure is strengthened by direct observations of $\mathrm{CO}_{2}$-rich fluid inclusions, carbonates, carbonatebearing glass veins and melt pockets in wehrlites, with entrapment pressures of 0.8 to 1.7 GPa (e.g., Yaxley et al., 1998; Loges et al., 2019). It is further supported by experimental studies which show that wehrlite forms in equilibrium with carbonated melts (Yaxley and Green, 1996; Gervasoni et al., 2017).

The effects of wehrlitisation on major element contents vary (Fig. S-2), reflecting the spectrum of $\mathrm{SiO}_{2}$-undersaturated carbonated melts. In some suites (e.g., Eifel, North Atlantic Craton in Greenland), clinopyroxene in wehrlite is dominated by elevated $\mathrm{CaO} / \mathrm{Al}_{2} \mathrm{O}_{3}$ (Figs. 2a, S-2), in others by elevated
FeO (Fig. 2b). The effects on the trace element budget are also heterogeneous (Fig. S-3), depending not only on the identity of the metasomatic agent and type of melt-rock reaction, but also on lithosphere thickness, as the melt traverses and equilibrates with garnet-bearing peridotite in thick lithospheres (Supplementary Information).

\section{Modelling $\mathrm{CO}_{2}$ Loss Via Wehrlitisation}

The amount of $\mathrm{CO}_{2}$ liberated from a volume of wehrlitebearing peridotite due to interaction with $\mathrm{CO}_{2}$-bearing, silicaundersaturated melt is estimated based on the decarbonation reaction

$$
\underset{\text { Enstatite }}{4 \mathrm{MgSiO}_{3}}+\underset{\text { Dolomite }}{\mathrm{CaMg}\left(\mathrm{CO}_{3}\right)_{2}}=\underset{\text { Forsterite }}{2 \mathrm{Mg}_{2} \mathrm{SiO}_{4}}+\underset{\text { Diopside }}{\mathrm{CaMgSi}_{2} \mathrm{O}_{6}}+\underset{\text { Vapour }}{2 \mathrm{CO}_{2}}
$$

(e.g., Yaxley and Green, 1996). Dolomite is assumed to be dissolved in the metasomatic melt, and wehrlites with high clinopyroxene modes formed from lherzolites and harzburgites with lower clinopyroxene modes (Wallace and Green, 1988; Yaxley et al., 1998). The proportion of a rock mass affected by wehrlitisation is estimated by counting Fe-rich "reaction" dunites and orthopyroxene-poor harzburgites and lherzolites with wehrlites (hereafter "wehrlite-group peridotites"), compared to "other peridotites" comprising harzburgites and lherzolites with clinopyroxene/ orthopyroxene ratios $<1$. Reaction dunites, with low pyroxene modes, form during open-system processes (e.g., Shaw et al., 2018), whereas here an equilibrium process is modelled. Therefore, reaction dunites and olivine-rich harzburgites with high
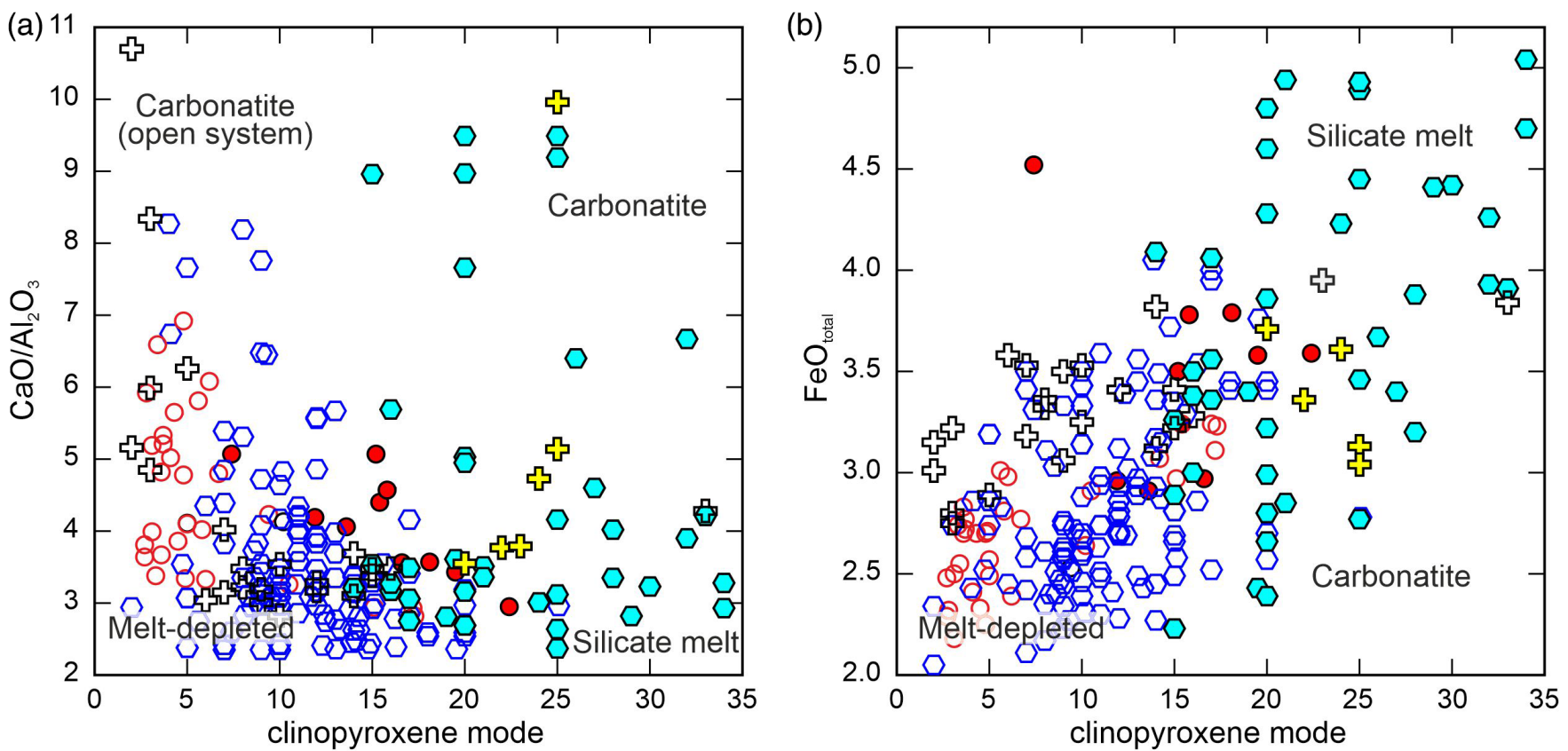

$$
\text { China (TLFB) O Siberia (Tok) § Middle Atlas Filled: Wehrlite-group / Open: Other peridotites }
$$

Figure 2 (a) $\mathrm{CaO} / \mathrm{Al}_{2} \mathrm{O}_{3}$ and (b) $\mathrm{FeO}_{\text {total }}$ content (wt. \%) in clinopyroxene from garnet-free xenoliths as a function of modal abundance (\%) of clinopyroxene (Table S-1), illustrating varied effects of wehrlitisation. The type of metasomatic agent is inferred on a suite-by-suite basis from the combined $\mathrm{FeO}$ and $\mathrm{CaO} / \mathrm{Al}_{2} \mathrm{O}_{3}$ characteristics of clinopyroxene in wehrlite-group peridotites (Fig. S-2). As an example, for the Tan Lu Fault Belt, wehrlites with clinopyroxene having $\mathrm{CaO} / \mathrm{Al}_{2} \mathrm{O}_{3}>6$ and $\mathrm{FeO}<3.5 \mathrm{wt} \%$ are assigned to the carbonatite-metasomatised suite, those with $\mathrm{CaO} / \mathrm{Al}_{2} \mathrm{O}_{3} \leq 6$ and $\mathrm{FeO} \geq 3.5 \mathrm{wt}$. \% to the silicate melt-metasomatised suite, and the remainder to the carbonated silicate melt-metasomatised suite. Filled symbols denote wehrlite-group peridotites, open symbols denote other peridotites. Orthopyroxene-poor, olivine-rich harzburgites and reaction dunites with low clinopyroxene modes likely interacted with silica-undersaturated melt during opensystem processes (Shaw et al., 2018). 
clinopyroxene/orthopyroxene ratios are not considered in the calculation of the median clinopyroxene abundance or composition in the wehrlite-group peridotites (Table S-3).

The calculations assume closed-system reactions, resulting in minimum estimates for the volume of silica-undersaturated melt passing through the shallow lithosphere (Yaxley et al., 1998). Because Equation 1 is based on diopside, whereas natural clinopyroxenes are not pure diopside, the difference in median clinopyroxene modes between wehrlite-group and other peridotites is weighted by the median diopside component in clinopyroxene $(\Delta \mathrm{Di})$. The mass of enstatite required to produce $\Delta \mathrm{Di}$ is calculated based on the decarbonation reaction, with two moles of $\mathrm{CO}_{2}$ liberated per mole of diopside formed (Eq. 1). The mass of $\mathrm{CO}_{2}$ that passed through the shallow lithosphere is estimated by weighting the mass of $\mathrm{CO}_{2}$ liberated during wehrlitisation by the proportion of wehrlite-group peridotites in each sample suite (Table S-3). The variation of the wehrlite-group proportion in multiple xenolith suites per area is taken as the uncertainty. The continental lithospheric area affected by wehrlitisation is estimated using area estimates from the literature or information on the total length of associated rifts, such as the Eastern Rift in the East African Rift and the European Cenozoic Rift System (Supplementary Information). Assuming a density of $3350 \mathrm{~kg} \mathrm{~m}^{-3}$ and a conservative $10 \mathrm{~km}$ interval of wehrlitisation, the total mass of liberated $\mathrm{CO}_{2}$ is estimated. Finally, disequilibrium textures indicate that wehrlitisation occurred close in time to entrainment in the host magma, and that no major fluid- or melt-rock interaction has occurred since. Thus, wehrlitisation and $\mathrm{CO}_{2}$ degassing are taken to be related to periods of active extension, which facilitates the formation and mobility of small-volume melts (Supplementary Information).

\section{Results and Discussion}

In the xenolith suites considered, 6-15\% clinopyroxene was added due to wehrlitisation (Table S-3), corresponding to $\Delta$ Di of 3.5 to $12 \%$ and requiring conversion of 6.4 to $22 \mathrm{~kg}$ of enstatite (Table 1). Weighted by the proportion of wehrlitegroup peridotites in the spinel facies rock column, this amounts to $0.2 \pm 0.1 \mathrm{~kg}$ (Hoggar Swell) to $2.4 \pm 1.5 \mathrm{~kg}$ (Eastern Rift) $\mathrm{CO}_{2}$ per $100 \mathrm{~kg}$ of wehrlitised peridotite (Table 1). The continental area affected by wehrlitisation ranges from $110 \times 10^{3} \mathrm{~km}^{2}$ (European Cenozoic Rift System) to $4500 \times 10^{3} \mathrm{~km}^{2}$ (Tan Lu Fault Belt). Taking the proportion (and its variability gauged as $1 \sigma$ ) of wehrlite-group peridotites entrained with basalts in each area as representative, this yields total masses of released $\mathrm{CO}_{2}$ from $24( \pm 15) \times 10^{3} \mathrm{Gt}$ to $2100( \pm 1700) \times 10^{3} \mathrm{Gt}$. For estimated timespans of activity from 10 to $40 \mathrm{Myr}$, this amounts to $\mathrm{CO}_{2}$ fluxes of $1.4 \pm 0.1 \mathrm{Mt} \mathrm{yr}^{-1}$ (Pannonian Basin) to $70 \pm 58 \mathrm{Mt} \mathrm{yr}^{-1}$ (Tan Lu Fault Belt) (Table 1). These estimates indicate significant mantle contributions to the total tectonic and volcanic $\mathrm{CO}_{2}$ flux at the time of active rifting. For comparison, for conservative flux densities, $40 \mathrm{Mt} \mathrm{CO}_{2} \mathrm{yr}^{-1}$ is estimated for combined presentday active rifts (Brune et al., 2017). Further, amplitudes $>80 \mathrm{Mt}$ $\mathrm{CO}_{2} \mathrm{yr}^{-1}$ are estimated for the "Mesozoic $\mathrm{CO}_{2}$ high", which was associated with a total rift length of 50,000 km (Brune et al., 2017). This suggests that the Tan Lu Fault Belt, which was most active in the Early Cretaceous, was a major contributor to the contemporaneous greenhouse climate. For the Eastern Rift, we obtain $\sim 6.5 \pm 4.1 \mathrm{Mt} \mathrm{CO}_{2} \mathrm{yr}^{-1}$ compared to 6-18 Mt $\mathrm{CO}_{2} \mathrm{yr}^{-1}$ attributed to magmatic intrusions into the crust based on surficial $\mathrm{CO}_{2}$ flux measurements (Hunt et al., 2017). The similar order of magnitude for estimated mantle contributions to $\mathrm{CO}_{2}$ degassing in the Eastern Rift suggests that wehrlites are well suited to monitor the present and past passage of $\mathrm{CO}_{2}$ through the shallow lithosphere, which ultimately degassed to the atmosphere. All $\mathrm{CO}_{2}$ mass estimates are minima because open-system processes (e.g., dunitisation) cannot be quantified using our method. Further, a proportion of clinopyroxene in lherzolites, which were attributed to "other peridotites", may have resulted from wehrlitisation instead. It is also possible that the affected lithospheric depth interval is $>10 \mathrm{~km}$ (e.g., in the North Atlantic Craton in Greenland it is $20 \mathrm{~km}$; Supplementary Information). Moreover, the width of the affected lithosphere adjacent to rifts may be broader than assumed here.

Modern degassing of mantle-derived $\mathrm{CO}_{2}$-rich fluids and gases is correlated to active fault systems and extensional tectonic regimes (Brune et al., 2017; Tamburello et al., 2018). A link

Table 1 Modelled loss of $\mathrm{CO}_{2}$ from spinel peridotite due to wehrlitisation.

\begin{tabular}{|l|c|c|c|c|c|c|c|}
\hline \multicolumn{1}{|c|}{ Locality } & Agent & Area/duration & $\Delta \mathrm{Di}^{\mathrm{c}}$ & Enstatite $^{\mathrm{d}}$ & Dolomite $^{\mathrm{e}}$ & ${\text { Perid } \mathrm{CO}_{2}(1 \sigma)^{\mathrm{f}}}^{\left.\mathrm{CO}_{2} \mathrm{flux}_{(1 \sigma}\right)^{\mathrm{g}}}$ \\
\hline Unit & & $1000 \mathrm{~km}^{2} / \mathrm{Myr}$ & $\%$ & $\mathrm{~kg}$ & $\mathrm{~kg}$ & $\mathrm{~kg}$ & $\mathrm{Mt} \mathrm{yr}{ }^{-1}$ \\
Eastern Rift & 2 & $600 / 40$ & 9.3 & 20 & 9.3 & $2.4(1.5)$ & $6.5(4.1)$ \\
Aldan Shield & 3 & $200 / 10$ & 7.1 & 13 & 6.1 & $0.6(0.4)$ & $4.1(2.4)$ \\
TLFB type 1 & 1 & & 8.4 & 16 & 7.1 & $0.3(0.3)$ & $16(13)$ \\
TLFB type 2 & 2 & & 12 & 22 & 10.2 & $0.3(0.2)$ & $13(11)$ \\
TLFB type 3 & 3 & & 9.5 & 18 & 8.0 & $0.8(0.7)$ & $41(34)$ \\
TLFB combined & $1,2,3$ & $4500 / 30$ & & & 9.4 & $1.4(1.2)$ & $70(58)$ \\
Middle Atlas & 2 & $400 / 40$ & 11 & 20 & 2.9 & $0.2(0.4)$ & $5.1(1.2)$ \\
Hoggar Swell & 3 & $785 / 40$ & 3.5 & 6.4 & 8.8 & $1.9(1.2)$ & $1.5(0.8)$ \\
WEVF & 2 & $110 / 40$ & 10 & 19 & 7.4 & $0.6(0.1)$ & $1.4(0.1)$ \\
Pannonian basin & 3 & $133 / 20$ & 8.7 & 16 & & & \\
\hline
\end{tabular}

TLFB Tan Lu Fault Belt, WEVF West Eifel Volcanic Field

a Type of metasomatic agent involved in wehrlitisation: 1 carbonatite (40-48 wt. \% $\left.\mathrm{CO}_{2}\right), 2$ carbonated silicate melt $(10-30$ wt. \% CO $), 3$ silica-undersaturated silicate melt $\left(1-5\right.$ wt. \% $\left.\mathrm{CO}_{2}\right)$

bstimated area affected by wehrlitisation and duration of metasomatism/degassing

${ }^{c}$ Difference between median clinopyroxene abundances in wehrlite-group (reaction dunites not counted) and other peridotite xenoliths, weighted by median diopside component (Table S-3)

${ }^{\mathrm{d}}$ Mass of enstatite (per $100 \mathrm{~kg}$ of peridotite converted to wehrlite) required for conversion to mass of diopside corresponding to $\Delta \mathrm{Di}$

${ }^{\mathrm{e}}$ Mass of dolomite in the liquid (per $100 \mathrm{~kg}$ of peridotite converted to wehrlite) corresponding to $1 / 4$ of the moles of enstatite as per the decarbonation reaction: $4 \mathrm{MgSiO} \mathrm{O}_{3}+$ $\mathrm{CaMg}\left(\mathrm{CO}_{3}\right)_{2}=2 \mathrm{Mg}_{2} \mathrm{SiO}_{4}+\mathrm{CaMgSi}_{2} \mathrm{O}_{6}+2 \mathrm{CO}_{2}$

${ }^{\mathrm{f}}$ Mass of $\mathrm{CO}_{2}$ liberated from $100 \mathrm{~kg}$ wehrlite-bearing peridotite using proportion of wehrlite-group peridotites and its variability in Table S-3

${ }^{g}$ Megatonnes $\mathrm{CO}_{2}$ degassed per year for the estimated area and duration (comment b) 
between wehrlitisation and extensional settings is also evident in all cases studied here. Tamburello et al. (2018) find that current degassing is more prevalent in central Western Europe and the western United States than in cratonic areas. This probably reflects that extension leads to lithosphere thinning, as occurred in the Wyoming Craton and in eastern North China Craton, which hosts part of the Tan Lu Fault Belt. In these settings, oxidised melts collect carbon previously stored in the SCLM (Foley and Fischer, 2017), followed by decarbonation as the melts encounter the solidus ledge of carbonated peridotite (Wallace and Green, 1988). In this case, not only the lithosphere associated with rifts and faults that are recognisable at the surface should be regarded as potential sites of wehrlitisation and $\mathrm{CO}_{2}$ release, but also lithosphere affected by unsuccessful rifting and thinning, such as the North Atlantic Craton in Greenland, as well as cratonic regions recognised as partially or wholly decratonised (Aulbach, 2019). Moreover, deep lithosphere loss causes lithospheric heating and decompression, as evidenced by microstructural and compositional evidence for garnet breakdown (Supplementary Information). This might not only exhume diamondiferous lithosphere to the shallower mantle where it is oxidised, but also causes crustal metamorphism, which is an important contributor to atmospheric $\mathrm{CO}_{2}$ (Kerrick, 2001).

\section{Conclusions and Outlook}

Wehrlites typically constitute $20 \%$ of mantle xenolith suites in extensional settings, where continental lithospheres are thinned, facilitating the generation and percolation of small-volume carbonated melts along rifts, faults or in basins. The decarbonation reaction can be applied to wehrlites to estimate the minimum amount of $\mathrm{CO}_{2}$ that passed through the shallow $(\sim 60-100 \mathrm{~km})$ lithosphere. Based on wehrlite-bearing xenolith suites, we calculate $\mathrm{CO}_{2}$ liberation of $24 \pm 15$ thousand to $2.1 \pm 1.7$ million Gt $\mathrm{CO}_{2}$, with estimated $\mathrm{CO}_{2}$ fluxes of $1.4 \pm 0.1 \mathrm{Mt} \mathrm{yr}^{-1}$ to $70 \pm$ $58 \mathrm{Mt} \mathrm{yr}^{-1}$. Ultimate diffuse degassing of this $\mathrm{CO}_{2}$ is expected to significantly affect climate. Importantly, wehrlitisation may occur wherever continental lithosphere is reactivated, also in lithospheric provinces where prominent rifts are absent and carbonated melts have not been emplaced at the surface. One such example is the basaltic volcanic province of southeastern Australia, where not only the link between wehrlitisation and carbonatite was first established, but also gas fields rich in mantle-derived $\mathrm{CO}_{2}$ have been connected to the very volcanism that brought the wehrlite xenoliths to the surface (Supplementary Information).

\section{Acknowledgements}

This work and collaboration were stimulated by an invitation to SA and GMY to present at the Deep Carbon Observatory's Deep Carbon 2019: Launching the Next Decade of Deep Carbon Science meeting in Washington DC (USA), and by an Alexander von Humboldt Fellowship to GMY, which we gratefully acknowledge. It was written while SA was funded through German Research Foundation fellowship AU356/11. We thank Shantanu Keshav, an anonymous referee as well as the editor, Ambre Luguet, for their very thorough reviews and incisive comments.

Editor: Ambre Luguet

\section{Additional Information}

Supplementary Information accompanies this letter at http:// www.geochemicalperspectivesletters.org/article2031.

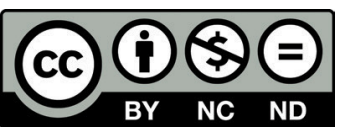

(C) 2020 The Authors. This work is distributed under the Creative Commons Attribution NonCommercial No-Derivatives 4.0 License, which permits unrestricted distribution provided the original author and source are credited. The material may not be adapted (remixed, transformed or built upon) or used for commercial purposes without written permission from the author. Additional information is available at http://www. geochemicalperspectivesletters.org/copyright-and-permissions.

Cite this letter as: Aulbach, S., Lin, A.-B., Weiss, Y., Yaxley, G.M. (2020) Wehrlites from continental mantle monitor the passage and degassing of carbonated melts. Geochem. Persp. Let. 15, 30-34

\section{References}

Aulbach, S. (2019) Cratonic Lithosphere Discontinuities: Dynamics of SmallVolume Melting, Meta-Cratonisation and a Possible Role for Brines. In: Yuan, H., Romanowicz, B. (Eds.) Lithospheric Discontinuities. American Geophysical Union, John Wiley \& Sons, Washington DC, 177-204.

Brune, S., Williams, S.E., Muller, R.D. (2017) Potential links between continental rifting, $\mathrm{CO}_{2}$ degassing and climate change through time. Nature Geoscience 10, 941-946

DASGUPTA, R., HiRsChMANn, M.M., SMITH, N.D. (2007) Partial melting experiments of peridotite $\mathrm{CO}_{2}$ at $3 \mathrm{GPa}$ and genesis of alkalic ocean island basalts. Journal of Petrology 48, 2093-2124.

FolEY, S.F., FisCHER, T.P. (2017) An essential role for continental rifts and lithosphere in the deep carbon cycle. Nature Geoscience 10, 897-902.

Gervasoni, F., Klemme, S., Rohrbach, A., Grützner, T., Berndt, J. (2017) Experimental constraints on mantle metasomatism caused by silicate and carbonate melts. Lithos 282-283, 173-186.

GudFinnsson, G.H., PRESNALl, D.C. (2005) Continuous gradations among primary carbonatitic, kimberlitic, melilititic, basaltic, picritic, and komatiitic melts in equilibrium with garnet lherzolite at 3-8GPa. Journal of Petrology 46, 1645equilib
1659.

Hirschmann, M.M. (2010) Partial melt in the oceanic low velocity zone. Physics of the Earth and Planetary Interiors 179, 60-71.

Hunt, J.A., Zafu, A., Mather, T.A., PYle, D.M., Barry, P.H. (2017) Spatially variable $\mathrm{CO}_{2}$ degassing in the main Ethiopian rift: implications for magma storage, volatile transport, and rift-related emissions. Geochemistry Geophysics Geosystems 18, 3714-3737.

KERRICK, D.M. (2001) Present and past nonanthropogenic $\mathrm{CO}_{2}$ degassing from the solid Earth. Reviews of Geophysics 39, 565-585.

Lin, A.-B., Zheng, J.-P., Aulbach, S., Xiong, Q., PAN, S.-K., Gerdes, A. (2020) Causes and consequences of wehrlitization beneath a trans-lithospheric fault: Evidence from Mesozoic basalt-borne wehrlite xenoliths from the TanLu fault belt, North China Craton. Journal of Geophysical Research: Solid Earth 124, e2019JB019084.

Loges, A., Schultze, D., Klügel, A., Lucassen, F. (2019) Phonolitic melt production by carbonatite Mantle metasomatism: evidence from Eger Graben xenoliths. Contributions to Mineralogy and Petrology 174, 93.

McKenZIE, D. (1989) Some remarks on the movement of small melt fractions in the mantle. Earth and Planetary Science Letters 95, 53-72.

RoHRBACH, A., SCHMidT, M.W. (2011) Redox freezing and melting in the Earth's deep mantle resulting from carbon-iron redox coupling. Nature 472, 209-212.

Shaw, C.S.J., LeberT, B.S., Woodland, A.B. (2018) Thermodynamic Modelling of Mantle-Melt Interaction Evidenced by Veined Wehrlite Xenoliths from the Rockeskyllerkopf Volcanic Complex, West Eifel Volcanic Field, Germany. Journal of Petrology 59, 59-86.

Tamburello, G., Pondrelli, S., Chiodini, G., Rouwet, D. (2018) Global-scale control of extensional tectonics on $\mathrm{CO}_{2}$ earth degassing. Nature Communications 9 , 4608 .

Wallace, M.E., Green, D.H. (1988) An experimental determination of primary carbonatite magma composition. Nature 335, 343-346.

YaxLEY, G.M., GREEN, D.H. (1996) Experimental reconstruction of sodic dolomitic carbonatite melts from metasomatised lithosphere. Contributions to Mineralogy and Petrology 124, 359-369.

YAXLey, G.M., Green, D.H., KAMENETSKY, V. (1998) Carbonatite metasomatism in the southeastern Australian lithosphere. Journal of Petrology 39, 1917-1930. 